\title{
An Empirical Study of CBI Applied in College English Teaching in the Post-Massification
}

\author{
You-gen Lou \\ School of Foreign Studies, Yangtze University Jingzhou City Hubei Province China \\ sevenrosa@126.com
}

\begin{abstract}
In the post-massification period, it is a beneficial attempt to the reform of English Teaching based on subject content for non-English-majored college students. Content-Based Instruction (CBI) has been defined as "the teaching of content or information in the language being learned with little or no direct or explicit effort to teach the language itself separately from the content being taught", which can make the students not only learn knowledge but also improve their foreign language ability in learning content. Results in this study showed that: in the post massification period, contentbased English teaching could improve the level of motivation and English language ability of students in their English learning, but CBI was not suitable for poor English learners with no good foreign language (English) basis.
\end{abstract}

Index Terms - CBI; College English Teaching; PostMassification Period

\section{Introduction}

June 1973, the famous American higher education sociologist Martin - Trow proposed development of higher education, "three-stage" theory; in 1990s, Japanese leading expert in higher education Youbenchang examined the country's higher education after the United States, Britain, he found that the development of higher education in the United Kingdom and Japan, there were the difference of the development of higher education of many other countries in different places. For example, Youbenchang found that Japanese higher education enrollment rate of school-age population growth to a certain extent began to stagnate without reaching the universal stage .By contrast, nontraditional adult students grew rapidly, its growth rate were even more than the traditional students, but these nontraditional adult students may enroll repeatedly This finding was also beyond Martin. Trow's theory, he defined this stage as "post-massification."

\section{Literature Review}

Content-Based Instruction (CBI) has been defined as "the teaching of content or information in the language being learned with little or no direct or explicit effort to teach the language itself separately from the content being taught" (Krahnke, as cited in Richards \& Rodgers, 2001, p. 204). This teaching approach is considered by many researchers an effective and realistic teaching method in terms of combining language and content learning. According to Crandall (1999), CBI can be used in various ways depending on the skills being taught and includes not only traditional teaching methods such as grammar-based instruction or vocabulary development but also contemporary approaches such as communicative language teaching and humanistic methods ( $\mathrm{p}$. 604). CBI is related to Krashen's "Monitor Model". Krashen(1982) emphasized ways of decreasing learner anxiety, such as providing interesting texts as well as meaningful activities, which are comprehensible to learners, and CBI has the following essential features: "learning a language through academic content, engaging in activities, developing proficiency in academic discourse, fostering the development of effective learning strategies" (Crandall, p. 604). Content-Based Instruction is based on three main theories of language and four teaching models. Three main theories of language are: "language is text and discoursebased," "language use draws on integrated skills," and "language is purposeful" (Crandall, p. 208). Four teaching models are "theme-based approach", "sheltered-content courses", "adjunct courses"," language for special purposes".

\section{Research Methods}

\section{A. Research design}

In order to make clear that in the post-massification period, 1) Does content-based instruction(CBI) help nonEnglish-majored college students improve their motivation to learn English? 2) Does content-based instruction help nonEnglish-majored college students improve their English language proficiency? 3) Is CBI beneficial to all students in English learning? A comparative research method was used in this study. The subjects were divided into control and experimental groups. And the conventional English teaching method was used in the control group, which focused on learning the form of the language and on teachers' teaching the knowledge of the language in the text, while the experimental group was taught by a new English teaching method, namely English learning based on subject content.

\section{B. Subjects}

In September 2014, 115 second-year non-Englishmajored undergraduates in 3 classes from Yangtze University participated in this study. Among the 115 subjects, 60 were females and 55males, average age 19 with Chinese as the main language. Their majors are chemistry, agriculture, history, plant protection, finance, biological technology. All 115 students who had learned college English one year and had passed CET4were divided into the control group (57 students) and the experimental group (58 students) according to their choices. Their level of education, family background, age, personality and life experiences and other factors were same, that was to say, their overall learning and cognitive 
abilities were almost equal. The second year, the experimental group were taught the subject content course Experimental Design the English original material as the course materials in English. The control group continued to learn conventional course material College English. The survey found that before the experiment, the experimental group and the control group showed no significant difference in learning motivation level( $\mathrm{t}=.139, \mathrm{p}=.446)($ Table1). Meanwhile, two groups of students in the English language ability was not significantly different $(\mathrm{t}=.163, \mathrm{p}=.968)$ (Table 2$)$. Therefore, we can say that the experimental and control groups is homogeneous before the experiment.

\section{Instruments}

The instruments used in the study were the English Learning Motivation Questionnaire, English Language Applied Ability and interview.

English Learning Motivation Gardner \& Lamber's language learning motivation, attitude / motivation test Scale AMTB (Attitude / Motivation Test Battery), as the survey tool in the study was used to measure students' English language learning motivation, and desire that the three-point Likert scale for scale, a total of 20 questions, which related to the motivation and desire 10 questions respectively. Prediction of internal reliability was .90 , meaning that the scale display was reliable.

English Language Applied Ability. The National College English Test band 6 (2013 New Style) (full score of 710) and the National CET Oral Test (full score of 15) as the English language tools were used in this study to test the ability of students to use English. Content of CET 6 were showed in Table 2.

Interviews: There was interviews with the experimental group of students about the course experimental design and the harvest of learning English through the subject content.

\section{Data Collection and Analyses}

Before the research experiment (July 2013) and after the experiment (July 2014) two surveys on English learning motivation and two tests on English language applied ability were conducted to compare changes between the two groups of students in English learning motivation and the ability to use English. In this study, social scientific software SPSS 17.0 was used for statistical analysis to the collected data, the results showed that, the internal consistency reliability of the use of questionnaires and survey papers reached more than .77 , indicating that the test results were reliable.

\section{Results and Analyses}

In this study, social sciences software SPSS17.0 was used for statistical analysis to collected data to obtain relevant results, and the results were discussed and analyzed.

\section{A. English Learning Motivation}

After the one-year experiment, students' English learning motivation were improved between the control group and the experimental group. At the end of the experiment, the control group was lower than the experimental group in the overall level of learning motivation $(\mathrm{t}=-1.62, \mathrm{p}=.053)$, while the control group was less strong desire than the experimental group to learn English $(\mathrm{t}=-1.17, \mathrm{p}=.022)$ (Table 1).

\section{B. English Applied Ability}

As showed in Table 2, after one-year experiments, the ability to use the English language in the control group and the experimental group were improved, but the ability to use English of the students in the control group was, in general, lower than the experimental group, which showed a significant difference $(\mathrm{t}=-6.237, \mathrm{p}=.034)$. Specifically, the control group was significantly inferior to the experimental group compared to the increase in the output of the skills, such as composition $(\mathrm{t}=-2.082, \mathrm{p}=.042)$ and oral $(\mathrm{t}=-2.107$, $\mathrm{p}=.0348)$, indicating that students in the experimental group in English writing skills and spoken English skills had been significantly improved. The control group was significantly inferior to the experimental group on the skills of reception, such as hearing $(\mathrm{t}=-2.121, \mathrm{p}=.037)$ and reading $(\mathrm{t}=-.585, \mathrm{p}$ $=.047)$, which showed that the experimental group in English Listening comprehension and reading comprehension had improved significantly. While there was no significant difference $(\mathrm{t}=.656, \mathrm{p}=.513)$ in the integrated skills (translation) between the control group and the experimental group.

\section{Discussion}

Needs to promote the development of learning motivation, and learning motivation was an important factor in the development of language learning. From Table 1, we know that, after one-year experiment the control group was lower than the experimental group in the overall level of learning motivation, especially the desire to learn English.

The main reasons are:

First, English courses teachers taught were required by non-English-majored college students. When teaching content related to the interest of learners, students would have a strong desire to learn subject content, this correlation was a prerequisite for maintaining long-term motivation to learn (Brinton,D.M.,M.A.Snow \& M.Wesche,2003).Some of students in the experimental group already had a strong interest in learning English, the teachers chose English language as a medium to teach curriculum content and design of experiments to help students learn needed academic knowledge. After the experiment, talked with the students in the experimental group we knew that they thought learning English as a medium to gain academic knowledge, which promoted the development of their English learning motivation.

Second, the course content was from the real experimental content and language content. In this study, original content-based English teaching materials was used for English textbooks, which was helpful for students develop their own experimental design. Students' learning motivation changed gradually from the instrumental motivation to integrative motivation.

Therefore, the combined effect of the differences on overall academic achievement between the two groups of students was contributed to the internal and external factors 
from two groups of learners in the experiment. Students in the experimental listened to teachers explain the subject content knowledge in English, after class they listening to and watching English programs related to the course, so that they were in English listening environment to enhance their listening ability of a great help.

After the experiment, researchers, after the conversation with students in the experimental group, knew that: some students with poor basic English foundation say they feel pressure increased and their ability to use the English language to be improved was not obvious in CBI. This indicated that the course content was limited to help students with poor English basis.

\section{Conclusion}

This study was designed to explore CBI in English teaching in the post-massification. Results in this study showed that: in the post massification period, content-based English teaching can improve the level of motivation and
English language ability of students in their English learning, but CBI is not suitable for poor English learners with no good foreign language (English) basis.

\section{References}

[1] Arnold Jane. Affect in Language Learning. Cambridge: Cambridge university press, 1998.

[2] Brinton, D.M., M.A.Snow \& M.Wesche. Content-based Second Language Instruction(Classics ED.). Ann Arbor, MI: University of Michigan Press, 2003.

[3] Brinton D. SNOW M. WESCHE. M. Content-based second language instruction. New York: Newbury House,1989:1-4.

[4] Crandall, J. Content-based instruction(CBI). Concise encyclopedia of educational linguistics. Oxford, UK: Cambridge University Press 1999.

[5] Maslow, A. H. 1970. Motivation and Personality. New York: Haler Row.

[6] Platt.C.W.1988.Effects of causal attributions for Success on first - term college performance: A covariance structure model. Journal of Educational Psychology80:569-57

[7] Richards, J., \& Rodgers, T. Approaches and methods in language teaching. New York: Cambridge University Press 2001.

Table1 Test of English learning motivation between C.G. and E.G.

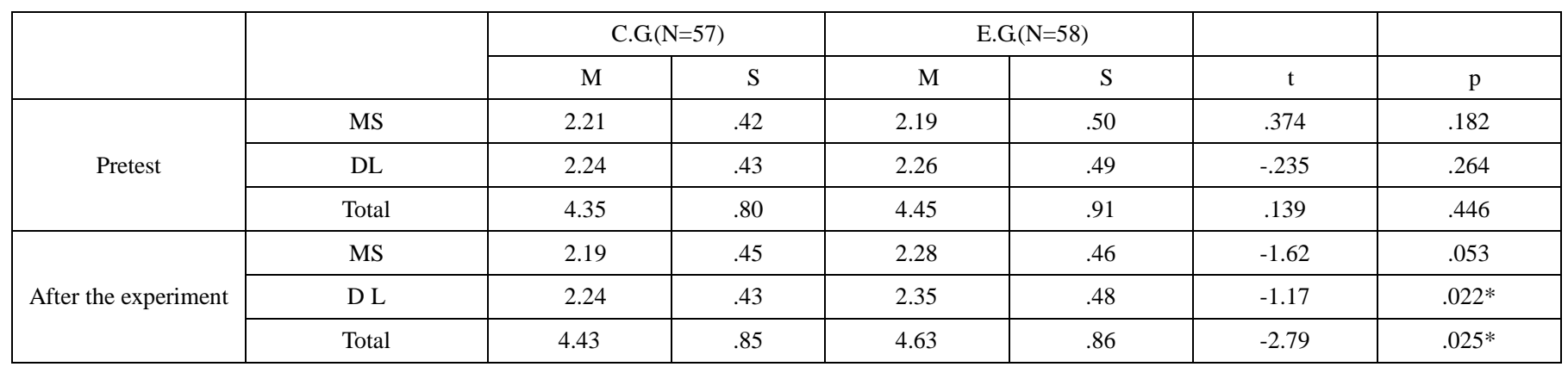

* means $p \leq .05$, C.G. for Control Group; E.G. for Experimental Group; MS for Motivation Strength; DL for Desire of Learning

Table2 Test of English Applied Ability between C.G. and E.G.

\begin{tabular}{|c|c|c|c|c|c|c|c|}
\hline & & \multicolumn{2}{|c|}{ C.G. $(\mathrm{N}=57)$} & \multicolumn{2}{|c|}{ E.G. $(\mathrm{N}=58)$} & \multirow[b]{2}{*}{$\mathrm{t}$} & \multirow[b]{2}{*}{$\mathrm{p}$} \\
\hline & & $\mathrm{M}$ & $S$ & M & $\mathrm{S}$ & & \\
\hline \multirow{4}{*}{ Pretest } & Composition & 87.17 & 9.04 & 86.60 & 9.86 & .277 & .837 \\
\hline & Reading & 147.12 & 11.82 & 148.60 & 11.28 & -.585 & .657 \\
\hline & Translation & 44.55 & 4.46 & 44.64 & 4.97 & -.092 & .658 \\
\hline & Total & 429.43 & 38.77 & 428.81 & 37.46 & 0.163 & .968 \\
\hline \multirow{3}{*}{$\begin{array}{l}\text { After the } \\
\text { experiment }\end{array}$} & Composition & 85.21 & 8.24 & 89.12 & 8.32 & -2.082 & $.042^{*}$ \\
\hline & Listening & 143.1 & 9.45 & 145.2 & 9.12 & -2.121 & $.037 *$ \\
\hline & Reading & 149.02 & 10.82 & 151.210 & 9.28 & -.585 & $.047^{*}$ \\
\hline
\end{tabular}

* means $\mathrm{p} \leq .05$, C.G. stands for Control Group; E.G. stands for Experimental Group 